after the wound had been inflicted in order to obtain the greatest benefit. Fifty-six papers were presented to this Section, many of which will appear in scientific journals. Space permits the mention of the two in. vited papers only. That by Dr. Babkin, on "Secretory Mechanism of the Digestive Glands", contained a survey of the work of his laboratory on this subject. Briefly, it may be stated that the investigations have established that the mucous, demilune and myoepithelial cell groups of the submaxillary gland each have a separate innervation, and that the surface epithelium cells of the gastric mucosa and the mucoid, peptic and parietal cells of the gastric glands are under independent nervous or humoral control. The conclusions to be derived from this work were stated and further analysis of the secretory function of the digestive glands given. The second paper, by Prof. G. W. Scarth on "The Mechanism' of Frost Resistance", contained an account of the modes of frost injury to plant cells and of the protoplasmic changes which accompany frost-hardening. He also discussed how the different hardening changes afford protection. The new president of this Section is Prof. H. S. Jackson.

At the general meeting, Monsignor Olivier Maurault, rector of the University of Montreal and a fellow of Section I, was elected president of the Society, and Prof. J. K. Robertson was elected vice-president. David A. KeYs.

\section{HERMIT CRABS FROM THE JOHN MURRAY EXPEDITION}

$\mathrm{D}$ R. E. F. THOMPSON has published some interesting facts in the report referred to below* of collections obtained by the John Murray Expedition. The stations at which the Pagurids were taken are confined to the Gulf of Oman, the south Arabian coast, the Gulf of Aden, the East African coast, the Zanzibar region and the Maldive area, that is to say to the coastal regions and the two Gulfs.

The littoral and shallow-water forms are related. to those of the rest of the Indo-Pacific region. The deep-water forms may be divided into those living at mid-depths, which have considerable affinity with those of the North Atlantic, and the only truly abyssal form Parapagurus pilosimanus, which occurs at great depths around the edges of every ocean basin in the world. Nothing is known of the lifehistory of this species. It has always been recorded as housed in a typical zoophyte growth. In the present collection this was not the case; a number of different shells were used, the most frequent being Ianthina. The zoophyte house begins around a shell, and the author has found in two specimens examined from the North Atlantic that this basis was also on Ianthina.

Paguropsis typica, hitherto only known from the Philippines, the Gulf of Martaban and Cape Comorin, was found in the Zanzibar region, thus extending its known distribution another 2,000 miles round the world. Its range in depth is only 32 metres, although its geographical distribution is so wide.

The one new species described is a Sympagurus, S. burkenroadi. The suggestion that the three specimens of Glaucothoe, attributed to $G$. hendersoni,

* Pagurida and Conobitida. By Dr. E. F. Thompson. (The John Murray Expedition 1933-34, Scientific Reports, 7, No. 5, 1943.) (London: British Museum (Natural History).) found in the collection may be the larvæ of $S$. burkenroadi is most interesting. Whether the large symmetrical deep-water pagurids known as Glaucothoe are adults or larvæ is now practically settled in favour of the latter view, but it is still a matter of controversy as to whether they are abnormal or normal larval forms-the larvæ of small pagurids which have failed to find a shell and consequently have continued to grow in a larval state, or merely natural larvæ of large forms. The latter solution appears most likely to be the correct one, and Dr. Thompson has brought the matter further by finding these Glaucothoes inhabiting shells, with the abdomen twisted, but still with paired abdominal appendages and a symmetrical tail fan. Thus they are further developed towards adult pagurids than any specimen previously recorded. If they are normal larvæ, they must belong to large adults. In the present case the adult is very probably a Sympagurus, and the characters, except for those which are purely larval, agree very closely with those of $S$. burkenroadi. Moreover, one was found inhabiting the same species of shell. We are certainly well on the way to solving the 'Glaucothoe problem'.

\section{HIGH CRYSTAL HARMONICS FOR OSCILLATOR CONTROL}

A Narticle on this subject by I.E. Fair (Bell Lab. Rec:, 21, No. 8; April, 1943) points out that stability is one of the major requirements for oscillators controlling the frequency of radio transmitters. In ultra-high-frequency transmitters it assumes particular importance because a very small percentage change in the frequency of the controlling oscillator rnay shift the transmitted band many thousands of cycles. At $100 \mathrm{mc}$., for example, a $0 \cdot 01$ per cent change in frequency means a change of $10 \mathrm{kc}$., which is as much as the entire width of a broadeast band. Stability in oscillators is secured by some form of twaned circuit. The reactance of such a circuit changes slowly with frequency except over a narrow band in the region of resonance, where a small ehange in frequency is accompanied by a very large change in reactance, this latter enabling the resonant circuit to cuct as a frequency stabilizing element. Quartz crystals are eminently suited to control in this way because of their very sharp resonance, which is due to their low values of coupling and dissipation. Their characteristics change only slightly with variations in temperature and voltage, and thus high stability under all conditions is more easily obtained with them than with elements having higher dissipation or greater sensitiveness and voltage.

With the type of crystal most commonly used for oscillators, the frequency of resonance is inversely proportional to the thickness of the crystal. At 10 mc., for example, the thickness of the crystal is only about $6 \frac{1}{2}$ thousandths of an inch. Before being used in an ozillator, the crystal must be ground accurately to have parallel faces and to the desired thickness; satisfactory grinding becomes impracticable for crystals appreciably thinner than this. For transmitters requiring higher frequencies it has been almost universal practice to use a crystal with its fundamental resonance below $10 \mathrm{mc}$. and to employ a harmonic generator to secure the desired high frequency. So far as stability is concerned, this method is satisfactory, but it requires a very appre- 
ciable amount of additional apparatus. Not only does the cost of the oscillator go up, but the size also increases, and for many of the high-frequency applications, space is at a premium.

Practically all the circuits used for quartz crystal oscillators require that the reactance of the crystal be positive at the operating point. While harmonics of the fundmmental crystal frequency may be used with this type of circuit, therefore, only those giving a positive reactance are possible. Oscillators for a large part of the ultra-high-frequency range have thus been forced to employ harmonic generators, since the 5th harmonic of the thinnest usable crystal is only about $50 \mathrm{mc}$. This situation has now been ehanged by a circuit developed in these Laboratories and described in tho article, which permits crystal harmonies at least as high as the 23rd to be used for direct control of an oscillator circuit. Oscillators have been built for frequencies as high as $150 \mathrm{mc}$., using crystals with fundamental frequencios below $10 \mathrm{mc}$.

\section{SINHALA WEAPONS AND ARMOUR}

THE Journal of the Ceylon Branch of the Royal Asiatic Society for December 1942 contains an article by P. E. P. Deraniyagala on "Sinhala Weapons and Armor". The work of the Sinhalese armourers seems to have elicited great praise from Europeans of the seventeenth century, but one may legitimately doubt whether tempering swords in blood or milk made them any better as weapons, unless it were that they gave greater confidence. The Sinhalese court went in, apparently, for gladiatorial shows; fencing was taught, and foils (or singlesticks) were used in mock combat. The weapons illustrated include the boomerang, both of horn and of wood, and it is worth noting that the Koli name for it is katariya: very suggestive of the Latin name for itcateia. The prevalence of the leaf-shaped sword is striking. It is interesting to find in use the feathered javelin, if one can so describe it when the 'feather' was made of metal. Possibly the flat metal vanes were derived from vanes of pandanus leaf such as are used both for crossbow bolts and for javelins in the Assam hills.

A javelin feathered like an arrow appears in the hand of a god or hero in one of 'Titian's paintings, and Barbosa depicted a similar weapon in the hand of the King of Cochin riding on his elephant; some Eskimo harpoons are so constructed, but the type is a rare one. The author's description of a Sinhalese blowgun is tantalizing. Since he describes it as a wooden tube, it is presumably bored from wood in a single piece. Nlowguns of this kind are rarely so long as 80 in. except in Borneo. The tube is tapered, and we are told that "the poisoned dart was fixed with a lump of clay" at the nozzle and propelled by blowing up the tube from the other end, which sounds highly improbable, not to say inefficiont. A detailed account of these blowguns, their use and manufacture, of the darts, and of the poison used is much to be desired, as well as some account of the toy blowguns which we are told are still in use. Some of the other descriptions also leave much to be desired. The illustrations are good, but the author is probably wrong in describing Plate I, $b$, as representing wrestlers; the lefthand figure appears to be female and the other to be seated. In general, however, the article contains a useful and well-illustrated account of antiquated Sinhalese weapons.

\section{FORTHCOMING EVENTS}

\author{
Saturday, September 25
}

British Pgychologicat Society (at Tavistock House, Tavistock Square, London, W.C.1), at 2.30 p.m.- "Education of the Adolescent".

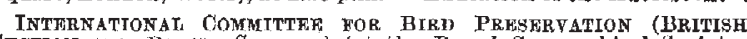
SECTION AND POLXSH SECHION) (at the Royal Geographical Society, Kensington Gore, London, S.W.7), at 2.30 p.m.-Dr. Jul. Borucki : "British Featherland" (colour flm).

\section{Tuesday, September 28}

BRITISH SOCIETY FOR INTERNATIONAL BIBIIOGRAPHY (at the Science Museum, Exhibition Road, South Kensington, London, S.W.7), at 4.30 p.m.-Prof. A. F. C. Pollard: "A Proposed Institute of Information".

ShefField Metallukgioal Association and SHeFhield SoOLety OF ENGINEERS AND METALLURGISTS (at the Royal Victoria Station Hotel, Sheffield), at 6.0 p.m.-Sir Lawrenee Bragg, F.R.S.: "The Strength of Metals".

\section{Wednesday, September 29}

Manchester Matalitrateat Society, The Imgtitute of Matatis and THE IRON AND STEFi INSTTTOTE (at the Engineer's Club Albert Square, Manchester), at 6.30 p.m.-Dr. W. H. Taylor: "Lattice Structures in Relation to Physical Propertics of Metals".

\section{Friday, October 1}

Association of APPLIFD BIOLOGISTs (at the Imperial College of Science and Technology, South Kensington, London, S.W.7), at 11 a.m. Symposing

Saturday, October 2

Assooration of SOIEn'irio Workers (at Essex Hall, Lissex Street Strand, London, W.C.2), at 2.30 p.m. Conference on "Problems of Freed Europe-The Challenge to the Medical Sciences". Problems of the Occupied Territories: Belgium (Dr. A. Marteau); Czecho(Prof. S. A. Sarkisov); Present Plans for Relief (Prof. J. R. Marrack). Grologists' Association (at the Geological Society, Burlington House, Piccadilly, London, W.1), at 2.30 p.m.-Mr. G. S. Swecting: "Wouse, Piccadilly, London, W.1), at 2.30 p.m.-Mr.G.

\section{APPOINTMENTS VACANT}

Appuroations are invited for the following appointments on or before the dates mentioned:

HEADS OF THE DEPARTMFNTS OF PHYSIOLOGY, MEDIOINE, AND SURGERY-The Bursar, Royal Veterinary College and Hospital, at The University, Reading (October 1).

FintCATIONAi PSYOHOLOGISI (full-time) to work in the Child Guidance Clinic-The Director of Education, Education Office, 'Iown Hall, Bradford (October 2).

Educational Psychologist (full-time) to be responsible for the direction of the child Guidance Clinic, and A PSYchIATRIst (part-time) -The Director of Education, Education Offices, Woodlands Road, Middlesbrough (October 2).

CHAIR OF NAVAL ARChTTECTURE-The Acting Secretary of University Court, The University, Glasgow (October 4).

HEADMASTER of the Montgomeryshire County Junior Technical School, Newtown-The Director of Education, county Offices, Newtown, Montgomeryshire (October 9).

AGRIOULTURAL EDUCATTON OFFICER-The Executive Officer, War Agricultural Exeoutive Committee, County Offices, Aylesbury, Bucks. (Óctcber 11).

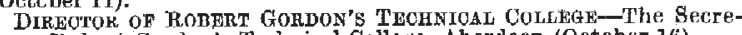
tary, Robert Gordon's Tenhnical College, Aberdeen (Oetober 16). PROFESSOR OF HNGINERRTA-The Registrar, University College, Singleton Park, Swansea (November 20).

SOIENCE Master to teaCh Chemistry and Phrstes at a lcading Boys' School, Jamaica-The British Council, 3 Hanover Street, London, W.1 (endorsed 'Jamaica').

LACTURFR IN NATURAL HISTORY-The Principal, Saffron Walden Trajnitig College, Saffron Walden.

LEOTURER IN NATURE STUDY AND BIOLOGY-The Principal, Dudley Training College, Castle Vicw, Dudlcy.

TOIATITIAN (WOMAN) in the Food Advice Division of the Ministry of Food-The Secretary Central (Technical and Scientific) Register, Ministry of Labour and National Service, Alexandra House, Kingsway, London, W.C.2 (quoting Reference No. ON.F.1425).

condon, W.C.2 (quoting Rerere in the Army Overseas-Ministry of FOOD ANALYSTS for serviee in the Army (Technical and Scientific) Labour and National Register, Alexandra

Dran with considerable experience in workshop DIRECTOR (ENGIN ER with constar operations, Beacher Strect, London, W.1 (endorsed 'Ethiopia').

Strect, London, W.1 (endored on ASSTSTANT MECHANIOAL FNGINEER for mine on Gold Coast engaged on production of essential war material-The Ministry of Labour and National Service, Central ('Technical and Scientific) Register, AlexC.1865X). 